González Castro, Carmen.

Artista visual y doctora en bellas artes, Universidad de Granada.

\title{
Hacia una metodología del proceso creativo y su validación en el ámbito de investigación académico.
}

\section{Towards a methodology of the creative process and its validation into the field of academic research.}

\author{
TIPO DE TRABAJO:
}

Comunicación.

PALABRAS CLAVE:

Arte contemporáneo, proceso creativo, metodología, investigación.

KEY WORDS:

Contemporary art, creative process, methodology, research.

\section{RESUMEN.}

Esta comunicación está dirigida a la exploración de una posible metodología del proceso creativo, y forma parte de un trabajo de investigación más amplio llevado a cabo en el marco del Máster de Investigación en Arte y Creación de la Universidad Complutense de Madrid.

\begin{abstract}
La hipótesis que se pretende demostrar es que es posible definir una metodología de la creación artística a partir del contraste entre una serie de casos de estudio y la reflexión de los artistas sobre su propio proceso creativo. A dicho proceso se atribuye una alta carga de intuición. Esta suposición será aquí rebatida como idea ligada al mito del genio creador y defendida en los términos que definen la idea de investigación dentro del ámbito académico.
\end{abstract}

Para tal fin, utilizaremos, como punto de partida, una entrevista realizada a la artista Soledad Sevilla. Partiendo de la base de la ausencia de una terminología establecida para definir qué significa la investigación en la creación artística, la entrevista se contrastará con otra realizada en el contexto del proyecto Grid_Spinoza a la bióloga Cristina Pujades. El objetivo es mostrar algunas de las diferencias y convergencias en los dos tipos de investigación, artístico y científico, para, en la medida de lo posible, clarificar y matizar los procesos y terminología específicos de ambos. Habiendo encontrado términos análogos en los dos campos, creemos que es posible validar desde una perspectiva académica la investigación artística.

Con ello, se espera poder llegar a conclusiones en torno a la especificidad de dicha investigación para darle cabida dentro del formato y las convenciones de lo que se ha venido entendiendo como contexto académico, y, por tanto y únicamente, de las prácticas investigadoras de las disciplinas científicas. 


\section{ABSTRACT.}

This paper examines the possibility of designing a methodology of the creative process. It comes after a wider research that was conducted within the context of the MA on Research on Art and Creation of the Universidad Complutense in Madrid.

The hypothesis that we aim to develop is that it is possible to trace a methodology of the artistic creation by comparing several study cases with the reflection of artists on their own creative process. This process is very often bound to the idea of intuition. The commonly assumed awareness of intuition as a concept entwined with the myth of the creative genius is to be questioned here. We will expose the terms that define the idea of research into the academic field.

To achieve this, we will begin by using an interview with the artist Soledad Sevilla. Our starting point is the lack of a specific terminology that could define the meaning of researching on art. We will contrast this interview with another one with the biologist Cristina Pujades, a member of the project Grid_Spinoza. Our objective is to show some of the differences and confluences in both types of research, artistic and scientific, to, as far as we are able, clarify the specific processes and terminology of both. Having found similar terms in these two fields, we believe that artistic research is very likely to be validated from an academic point of view.

We expect to come to a conclusion about the specificity of the artistic research, in order to find a place for it within the conventions of what is understood as academic context, that is to say, of the research practices in science. 